\title{
The Altman Model and Auditor's Opinion About Going Concern of the Companies
}

\author{
Ika Prayanthi, Nadya Gabriela Chordina Kakunsi
}

Departement of Economic Faculty, Universitas Klabat, Airmadidi, Indonesia

Email address:

ikaprayanthi@unklab.ac.id (I. Prayanthi),nadyagabrielak@yahoo.com (N. G. C. Kakunsi)

To cite this article:

Ika Prayanthi, Nadya Gabriela Chordina Kakunsi. The Altman Model and Auditor's Opinion About Going Concern of the Companies. Science Journal of Business and Management. Vol. 5, No. 5, 2017, pp. 189-193. doi: 10.11648/j.sjbm.20170505.12

Received: September 23, 2017; Accepted: November 3, 2017; Published: November 17, 2017

\begin{abstract}
This study aimed to examine whether the financial performance, in this case the predictions of Altman Model affect audit going concern opinion. The samples in this study consist of 59 companies and data variables are taken from the Indonesian Capital Market Directory and annual financial statement reporting. This study utilizes the logistic regression. The results from the logistic regression analysis show that every year in the period of the study 2012-2014, percentage correct of research model are $86,4 \%, 88.1 \%$, and $93.2 \%$ respectively. This research also found that every year in the period of study that there is a negative significant effect on prediction of the Altman model towards the audit going concern opinion. In other word, the more a company's predicted secure by Altman Model, the less likely get a going concern audit opinion. Descriptive analysis also prove that Altman prediction for grey area and secure area are really good in predict auditor's opinion but not really good in Altman prediction for bankruptcy area.
\end{abstract}

Keywords: Altman Model, Auditor's Opinion, Going Concern

\section{Introduction}

Financial report is the main source of information to all parties who have interests in a company [15]. Wulandari [20] emphasized that financial report itself can picture a financial position. Besides, [1] also stated that through financial report, we can get a picture on the life of a company, whether it is in a good condition or it has a tendency to go bankrupt.

In order for the financial statements that have been made by the company to be trustworthy and reliable, the auditor is required to play in bridging the interests of users and providers of financial report [20]. Besides having responsibility to assess whether there is any doubt greatly to his opinions on the financial report, based on auditor's regulations, auditor is required to provide an opinion regarding the company's ability to survive (going concern) in period of not more than one year from the date of the audit report [8].

Going concern audit opinion is the auditor's opinion that has been issued to ascertain whether companies can maintain their life or not [1]. In other words, companies that get a going concern audit opinion have indications cannot continue their business sustainability.
According to Dewi [5], giving opinions about the survival of a company (going concern) will affect the decision of users of financial statements. Further, it is said that if the auditor gives the wrong opinion about the survival of a company it will have a significant impact for the users of financial statements. Knowing the importance of the function of giving the auditor's opinion regarding the going concern of a company, it is important for the auditor himself/herself to be able to analyze the situation of a company.

In connection with these and associated with the function of financial statements themselves, there is a model that is the Altman model which serves to predict the survival of a company which in this study the researcher wanted to determine whether this prediction model for bankruptcy has an influence to the tendency of opinions about the survival of a company. Based on the explanation above, the researcher is interested to conduct the study with the title "The Altman models and Auditors opinion about going concern of the companies" that use the object consistent manufacturing companies listed in Indonesia Stock Exchange in 2012-2014 period. 


\section{Formulation of the Problem}

The formulation of the problem in this study is whether the company's financial condition that is peroxided by Altman model has a significant effect on the tendency of going concern audit opinion?

\section{Literature Review}

\subsection{Agency Theory}

Jensen and Meckling [9] describe the agency relationship as a contract under one or more principal involving an agent to perform some services for them by delegating decisionmaking authority to the agent. However, both the principal and the agent are assumed to be a rational economic person and solely motivated by personal interests. So that it is possible for the agency to act or behave deviate from fulfilling its interests Shareholders [6]. This is also corroborated by Praptitorini and Januarti [13] that however, managers do not always act according to the desire of shareholders, in part because of the presence of moral hazard.

In correlation with that, auditor as a third party who is independent in terms of supervision of the financial statements is required to monitor the performance of management in order for the management to act in accordance with the interests of shareholders.

Besides reasonable opinion statements on the financial reports, shareholders also expected that the auditor can give an opinion about early warning regarding to the survival of a company $[10,13]$.

\subsection{Audit Opinion}

The audit opinion is the main information of the audit reports. Further it is said that in giving audit opinion, the auditor must go through several stages of the audit so that the audited financial statements can be given conclusions on opinions should be given [1]. The audit report containing the opinion / opinions on the financial statements is the last step in audit process that is based on professional belief of the auditor itself [4]. In addition to the auditor is required to give a statement on the fairness of the financial statements, the auditor is also required to provide an opinion regarding to the survival of a company. If it is found a company has the ability to maintain their life then the auditor will tend to give a non-going concern opinion. Conversely, if a company rated by the auditor there is a tendency to fail then the auditor will give a going concern audit opinion.

\subsection{Going Concern Opinion}

The survival of a company according to Indonesian Accountants Association [8] is a basic assumption in arranging financial statements. That means where each company can maintain its business activities both in short term and long term is the desire of each company [21].

If connected with the auditor's opinion, Fadilah and
Djamhuri [6] in their research said that the going concern audit opinion is an audit opinion with an explanatory paragraph regarding the auditor's judgment that there is incompetence or significant doubt on the viability of the company to run its operations in the future. This is also supported by Yunida that modification about going concern in the audit report is an indication that in auditor's assessment found the risks auditee cannot stay in business [21]. Furthermore it is said from the viewpoint of the auditor, the decision to give a going concern audit opinion should involve several stages of analysis. Furthermore it is said that the auditor should consider the results of operations, economic conditions affecting the company, the ability to pay the debt, and future liquidity needs.

According to [19] in his book explains that although the purpose of the audit is not intended to evaluate the financial health of a business, the auditor has a responsibility based on PSA 30 (SA 341) to evaluate whether the company has a business continuity. The conditions and the following events led to doubts about the ability of companies to have business continuity, they are:

1. Operational losses large enough or lack of working capital

2. The company's inability to pay its obligations on the due date.

3. The consumer loses, uninsured disaster, such as earthquakes or floods, or unusual employment problems.

4. Law demand, violation of law or the like which can interfere with the ability of the company to operate.

\subsection{The Financial Condition of the Company}

The financial condition of the company is a full view on the financial company during the period or certain period of time. Further, it is said the media that can be used to assess the financial condition of the company is a financial statements consist of balance sheet, profit and loss statement, overview of retained earnings, and statement of financial position. Further said that the company which the financial condition is bad, many found indicators of problems concerning its survival [4]. This is supported by Meriani and Krisnadewi in their research said that it is required a management capabilities in managing the company to maintain the viability of the company [12]. Due to financial problems will also affect the company's survival. This will certainly influence the opinion given by the auditor.

One way to assess the financial condition of the company is by using Altman model.

\subsection{The Altman Model}

One of the studies about company failure prediction is Multiple Discriminant Analysis conducted by Edward I. Altman. Altman found that company with low profitability and solvency has a potential of bankruptcy [2]. Altman developed the model of bankruptcy using 22 financial ratios which classified into five categories: liquidity, profitability, leverage, the ratio of market testing and activities. The 
Altman model are as follows:

$$
\mathrm{Z}=1.2 \mathrm{Z} 13.3 \mathrm{Z} 3+++1.4 \mathrm{Z} 20.6 \mathrm{Z} 4+0.999 \mathrm{Z} 5
$$

Description:

$\mathrm{Z}=$ Total Score Model Altman

$\mathrm{Z1}$ = working capital / total assets

$\mathrm{Z} 2$ = retained earnings / total assets

$\mathrm{Z3}=$ earnings before interest and taxes / total assets

$\mathrm{Z4}=$ market capitalization / book value of debt

$\mathrm{Z} 5$ = sales / total assets

1. Working capital / total assets

Working capital/total assets is used to measure the liquidity of the company's assets relative to total capitalization, or to measure the company's ability to meet short-term obligations. Indicators that can be used to detect problems at the level of liquidity of the company are the internal indicators such as insufficiency of cash, debt swells trade, utilization of capital declines, additional debt is uncontrollable and some other indicators.

2. Retained earnings / total assets

Retained earnings/total assets is used to measure the cumulative profitability. This ratio measures the accumulated profits during the company operates. Age of Companies effect on these ratios because the longer the company operates allows to accelerate the accumulation of retained earnings. This resulted in the company is still relatively new in general will show the result of a low ratio, except that a very large profit in its early years.

3. Earnings before interest and taxes / total assets

Earnings before interest and taxes/total assets is used to measure the actual productivity of the assets of the company. The ratio measures the company's ability to generate income from the assets that were used. This ratio is the biggest contributor of the model. Some ofa the indicators that we can use in detecting a problem with the ability of the profitability of these companies are receivables increased, the loss continuously in several quarters, increased inventory, sales declined and others.

4. Market capitalization / book value of debt

Market capitalization/book value of debt is used to measure how much of the company's assets may be impaired before the debt amount is greater than its assets, and the company became insolvent. Capital in question is the combined market value of the ordinary capital and preference shares, while debt includes current liabilities and long-term debt.

5. Sales / total assets

Sales/total assets is used to measure the ability of management in facing competitive conditions. The ratio measures the ability of management to use assets to generate sales.

Based on this analysis, if the $Z$ value of the studied company is smaller than 1.81 , then the company at high risk of bankruptcy, when the $Z$ value is between 1.81 until 2.99 it still have a risk of bankruptcy, when the $Z$ value above 2.99 the company is predicted to be in a safe condition.

In 1993, the model developed previously has been revised with the aim in order for the predictions model are not only used in manufacturing companies, but also can be used for the company in addition to manufacturing. The revised model Altman used for manufacturing companies are as follows:

$$
\begin{aligned}
& \mathrm{Z}=0.71 \mathrm{Z1} 3.107 \mathrm{Z3}+++0.874 \mathrm{Z} 20.420 \mathrm{Z} 4+0.998 \mathrm{Z} 5(2) \\
& \mathrm{Z} 1=\text { working capital } / \text { total assets } \\
& \mathrm{Z} 2=\text { retained earnings } / \text { total assets } \\
& \mathrm{Z} 3=\text { earnings before interest and taxes } / \text { total assets } \\
& \mathrm{Z} 4=\text { book value of equity / book value of debt } \\
& \mathrm{Z} 5=\text { sales / total assets }
\end{aligned}
$$

Based on this analysis, if the $\mathrm{Z}$ value of the studied company is smaller than 1.23-called zone $I$ is a high risk of bankruptcy, when the $\mathrm{Z}$ value is between 1.23 up to 2.90 , the firm predicted on the condition of gray areas and when the value of $\mathrm{Z}$ in above 2.90 , the company predicted in safe conditions of bankruptcy [3].

\subsection{The Financial Condition of the Company and Going-concern Audit Opinion}

The health level of the company can be found on the company's financial condition. At the company which financial condition is good then the auditor tend not to issue the going concern audit opinion [14]. In other words Auditor only give opinions about going concern if the company had difficulty continuing its survival. This is confirmed by studies that have been done previously which found that the better financial condition of the company, the less the auditor gives going concern audit opinion $[18,21,14,12,7,13,17$, $11,16]$.

But other researcher found that the company's financial condition has no effect on the provision of going concern audit opinion $[6,20]$.

\subsection{Research Hypothesis}

HA: Financial Condition of the company expressed by Altman model has a significant negative influence on the tendency of granting Going concern audit opinion.

The conceptual framework of this research can be seen in the framework below:

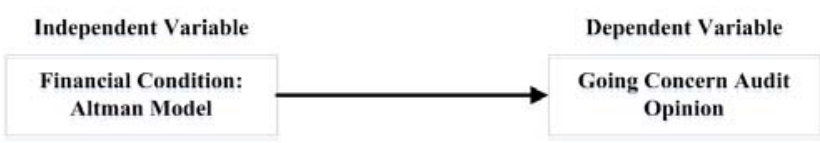

Figure 1. Conceptual Framework.

The independent variable in this study is the company's financial condition that is expressed using Altman model 1993. The dependent variable is a going concern audit opinion which is a dummy variable, where the categories 1 to companies that received a going concern audit opinion and category 0 for companies that receive non going concern audit opinion. The analysis in this study conducted annually by using logistic regression methods ranging from 2012 to 2014. 


\section{Research Methodology}

\subsection{Population and Sample}

In this study the population used are all manufacturing companies listed in Indonesia Stock Exchange in 2012-2014. For the selection of the sample, researchers using purposive sampling method.

The criteria for the samples used in this study are:

1. Companies of manufacturing sector registered consecutively in 2012-2014.

2. Companies of manufacturing sector published audited financial statements for the period ended December 31, 2012-2014. From the 66 companies that serve the population there are 59 companies that meet the criteria to be sampled.

\subsection{Statistics Formulas}

The logistic regression statistical formulas or models used to answer the hypothesis in this study are as follows:

$$
\operatorname{Ln} \frac{G C}{1-G C}=\propto+\beta_{1} Z S C O R E+\varepsilon
$$

Description:

$\operatorname{Ln} \frac{G C}{1-G C}=$ Dependent variable, Dummy variable

audit opinion (Category 1 to the auditee with the audit opinion going concern and 0 for non auditee with the audit opinion going concern

$\alpha=$ constant

$\beta 1=$ regression coefficient

ZSCORE=independent variable, financial condition proxied by using the revised models Altman.

$\mathrm{E}=$ random error

The error tolerance is set at 0.05 .

\section{Finding and Discussion}

\subsection{Descriptive Statistics}

Descriptive statistical results are shown in the tables below:

Table 1. Number of prediction Company Altman and Getting Opinion Audit and Non Going Concern.

\begin{tabular}{lllll}
\hline \multirow{2}{*}{ Year } & \multirow{2}{*}{ Prediction of Altman } & \multicolumn{2}{c}{ Auditor's Opinion } \\
\cline { 3 - 5 } 2012 & & GC & Non GC \\
\hline \multirow{2}{*}{2013} & Bankrupt & 11 & 6 & 5 \\
& Gray Area & 28 & 0 & 28 \\
& Safe & 20 & 1 & 19 \\
& Bankrupt & 18 & 8 & 10 \\
& Gray Area & 20 & 0 & 20 \\
& Safe & 21 & 0 & 21 \\
& Bankrupt & 12 & 5 & 7 \\
& Gray Area & 30 & 0 & 30 \\
& Safe & 17 & 0 & 17 \\
\hline
\end{tabular}

From Table 1 it can be seen that all the companies that are predicted by Altman models that are in the gray area $100 \%$ respectively in the study period get the audit opinion of nongoing concern. Likewise, for companies that are predicted by
Altman are in a safe area, although not $100 \%$ get a non-going concern audit opinion, but about $90 \%$ were found by the auditors were given a non-going concern opinion. But unlike the predictions Altman for companies that are in the area of bankruptcy. It can be found that some companies are predicted to be in the area of bankruptcy get a going concern audit opinion and some other companies get non going concern audit opinion.

Table 2. Percentage Determination Observation Classification Accuracy of the Model Study.

\begin{tabular}{ll}
\hline Year & Percentage Correct \\
\hline 2012 & 86.4 \\
2013 & 88.1 \\
2014 & 93.2 \\
\hline
\end{tabular}

\subsection{Hypothesis Test Results}

The test results $\mathrm{H}_{0}$ using logistic regression for each year can be seen in Table 3 below:

Table 3. Tabel test results null hypothesis using logistic regression for the years 2012-2014.

\begin{tabular}{lll}
\hline Year & Correlation & Sign \\
\hline 2012 & Negatif $(-)$ & 0.042 \\
2013 & Negatif $(-)$ & 0.003 \\
2014 & Negatif $(-)$ & 0.006 \\
\hline
\end{tabular}

Source: Data Processing with SPSS

\section{Conclusion and Limitation}

The conclusion that can be drawn from this study is that there is a negative significant effect between the model predictions Altman against going concern audit opinion. Where the more company is secure predicted by Model Altman then the tendency will be less for the company to get going concern audit opinion. Altman model is very good for the prediction of the audit opinion on the category of gray area and a safe area, but not very appropriate for the prediction of an audit opinion on the bankrupt category.

\section{References}

[1] Alichia, Y. P. (2013). Pengaruh Ukuran Perusahaan, Pertumbuhan Perusahaan, dan Opini Audit Tahun Sebelumnya Terhadap Opini Audit Going Concern (Studi Empiris Perusahaan Manufaktur yang Terdaftar Pada Bursa Efek Indonesia). Jurnal Akuntansi, 1 (1), 1-17.

[2] Altman, E. I. (1968). Financial Ratios, Discriminant Analysis And The Prediction Of Corporate Bankruptcy. The Journal Of Finance, XXIII (4), 589-609.

[3] Altman, E. I. (2000). Predicting Financial Distress of Companies: Revisiting the Z-Score and ZETA Models*.

[4] Arens, A. A. (2012). Auditing and Assurance Services. New Jersey: Prentice Hall.

[5] Dewi, S. P. (2011). Faktor-Faktor Yang Mempengaruhi Opini Going Concern. Jurnal Akuntansi, 11 (2), 513-538. 
[6] Fadilah, I., \& Djamhuri, A. (2014). Pengaruh Kadar Kebangkrutan Menurut Model Altman dan Opini Audit Tahun Sebelumnya Terhadap Penerimaan Opini Audit Going Concern (Studi Empiris Pada Perusahaan Manufaktur yang Terdaftar di BEI 2009-2011). Jurnal Ilmiah Mahasiswa FEB, $2(1), 1-20$.

[7] Fanny, M., \& Saputra, S. (2005). Opini Audit Going Concern: Kajian Berdasarkan Model Prediksi Kebangkrutan, Pertumbuhan Perusahaan, dan Reputasi Kantor Akuntan Publik (Studi Pada Emiten Bursa Efek Jakarta). Simposium Nasional Akuntansi VIII, (pp. 966-978). Solo.

[8] Ikatan Akuntan Indonesia. (2001). Standar profesional akuntan publik. Jakarta: Salemba Empat.

[9] Jensen, M. C., \& Meckling, W. H. (1976). Theory Of The Firm: Managerial Behavior, Agency Costs And Ownership Structure. Journal Of Financial Economics 3, 3 (1), 305-360.

[10] Komalasari, A. (2004). Analisis Pengaruh Kualitas Auditor dan Proxy Going Concern Terhadap Opini Auditor. Jurnal Akuntansi dan Keuangan, 9 (2), 1-15.

[11] Kurniati, W. (2012). Prediksi Kebangkrutan, Pertumbuhan Dan Reputasi KAP Terhadap Opini Audit Going Concern. Accounting Analysis Journal, 1 (1), 7-15.

[12] Meriani, N., \& Krisnadewi, K. A. (2012). Pengaruh Kondisi Keuangan, Pertumbuhan Perusahaan, Dan Reputasi Auditor Pada Pengungkapan Opini Audit Going Concern. Jurnal Ilmiah Akuntansi dan Bisnis, 7 (1), 1-29.

[13] Praptitorini, M. D., \& Januarti, I. (2007). Analisis Pengaruh Kualitas Audit, Debt Default dan Opinion Shopping Terhadap Penerimaan Opini Going Concern. Simposium Nasional Akuntansi X, (pp. 1-24). Makasar.
[14] Ramadhany, A. (2004). Analisis Faktor-Faktor Yang Mempengaruhi Penerimaan Opini Going Concern Pada Perusahaan Manufaktur Yang Mengalami Financial Distress Di Bursa Efek Jakarta. Skripsi, Universitas Diponegoro, Fakultas Ekonomi, Semarang.

[15] Reeve, J. M., Warren, C. S., \& Duchac, J. E. (2011). Principles of Accounting. Boston: South-Western Cengage Learning.

[16] Rudyawan, A. P., \& Badera, I. N. (2009). Opini Audit Going Concern: Kajian Berdasarkan Model Prediksi Kebangkrutan, Pertumbuhan Perusahaan, Leverage, Dan Reputasi Auditor. Jurnal Ilmiah Akuntansi dan Bisnis, 4 (2), 1-20.

[17] Siska, F. R. (2015). Pengaruh Audit Tenure, Disclosure, Ukuran KAP, Debt Default, Opinion Shopping dan Kondisi Keuangan Terhadap Penerimaan Opini Audit Going Concern. Jurnal Ekonomi, Manajemen dan Akuntansi I, 24 (1), 41-63.

[18] Susanto, Y. K. (2009). Faktor-faktor yang mempengaruhi penerimaan opini audit going concern pada perusahaan publik sektor manufaktur. Jurnal Bisnis dan Akuntansi, 11 (3), 155173.

[19] Tunggal, A. W. (2013). Pokok-Pokok Auditing \& Jasa Asurans. Jakarta: Harvarindo.

[20] Wulandari, S. (2014). Analisis Faktor-Faktor Yang Mempengaruhi Auditor Dalam Memberikan Opini Audit Going Concern. E-Jurnal Akuntansi Universitas Udayana, 6 (3), 531-558.

[21] Yunida, R., \& Wardhana, W. (2013). Pengaruh kualitas audit, kondisi keuangan perusahaan, opini audit tahun sebelumnya, pertumbuhan perusahaan terhadap opini audit Going Concern. Jurnal INTEKNA, Tahun XIII, 1 (1), 54-61. 